\title{
People, Land and Poppy: the Political Ecology of Opium and the Historical Impact of Alternative Development in Northwest Thailand.
}

\author{
Bobby Anderson ${ }^{1, *}$ \\ 1 Research Associate, School of Oriental and African Studies, University of London \\ * Correspondence author: rubashov@yahoo.com
}

\begin{abstract}
Thailand's near-total elimination of opium poppy cultivation is attributed to "alternative development" programming, which replaces illicit crops with licit ones. However, opium poppy cultivation was not drastically reduced because substitute crops earned the same income as opium: nothing can equal the price of opium to smallholder farmers, especially those without land tenure. Thailand's reduction in poppy cultivation was achieved by the increased presence and surveillance capability of state security actors, who, year by year, were able to locate and destroy fields, and arrest cultivators, with increasing accuracy. This coercion was also accompanied by benefits to cultivators, including the provision of health and education services and the extension of roads; both stick and carrot constituted the encroachment of the Thai state. The provision of citizenship to hill tribe members also gave them a vested interest in the state, through their ability to hold land, access health care, education and work opportunities, amongst others. These initiatives did not occur without costs to hill tribe cultures for whom a symbiotic relationship with the land was and remains disrupted. These findings indicate that alternative development programming unlinked to broader state-building initiatives in Afghanistan, Myanmar and other opium poppy-producing areas will fail, because short-term, high-yield, high value, imperishable opium will remain the most logical choice for poor farmers, especially given the lack of a farmer's vested interest in the state which compels them to reduce their income whilst offering them no other protections or services.
\end{abstract}

Keywords: Alternative Development; Crop Substitution; Drug Control; Forest Conservation; Hill Tribes; Opium Eradication; Thailand; Zomia

\section{Introduction}

Opium poppy cultivation in Thailand fell from 12,112 hectares in 1961 to 281 ha in 2015 . By most standards of measurement, the country's "war" on drug production succeeded, especially in comparison to other drug-producing countries such as Afghanistan, Myanmar, Laos, Colombia, Peru, Bolivia and Mexico. The United Nations Office on Drugs and Crime (UNODC) declared Thailand "opium free" a decade ago, and has not included Thailand in its World Drugs Report since 2008. Thailand is also widely heralded as a successful example of "alternative development" programming, which seeks to replace illicit crops with licit ones, and which is conducted in tandem with coercive policies to eliminate the opium economy, comprised of poppy cultivation, refinement into opium, conversion to heroin, and export.

This paper analyses the historical success of alternative development in Northern Thailand and finds that opium poppy cultivation was not drastically reduced because substitute crops earned the same income as opium: nothing can equal the price of opium to smallholder farmers, especially those without land tenure and the consecutive inability to securely invest in longer-term crops. Without eradication, opium cultivation is determined by market forces: in 1984, the year eradication began, cultivation was again peaking. But alternate crops did provide income, aided by a market-distorting price floor the government used to make up the difference. That price floor remains. The near-total reduction in opium cultivation, however, was aided by much more than new crops and price guarantees. The era of eradication was heralded by the increased presence of 
state security actors, enhanced law enforcement and surveillance, the destruction of crops, and the arrest of cultivators. But this coercion was also accompanied by benefits to hill tribes, including the provision of health and education services, the extension of roads, the assignment of civil servants to administer areas they were previously absent from. Both stick and carrot constituted the encroachment of the Thai state. The provision of citizenship to hill tribe members also gave them a vested interest in the state, through their ability to hold land, access health care, education and work opportunities, and bank credit, amongst others. These initiatives did not occur without both economic and cultural costs to hill tribe cultures for whom a symbiotic relationship with the land was and remains disrupted. Far from being a standalone historical episode unlinked to others, alternative development and eradication has occurred as a part of the centuries-long expansion and consolidation of lowland Thai state power into egalitarian and state-resistant highland areas it was previously absent from. This paper therefore applies the theoretical frameworks of Van Schendel (2002), and Scott (2009) toward Thailand's contemporary expansion into remote areas of Northwest Thailand.

These findings indicate that alternative development programming unlinked to broader state-building initiatives in Afghanistan, Myanmar and other opium poppy-producing areas will fail, because short-term, high-yield, high value, imperishable opium will remain the most logical choice for poor farmers, especially given the lack of a farmer's vested interest in the state which compels them to reduce their income whilst offering them no other protections or services.

This analysis is based on field research and interviews with Thai government officials, Hill Tribe representatives, security actors, academics, civil society representatives, local businesspersons, ex-cultivators, and recovering opium addicts in Omkoi, Chiang Mai, and other areas, from December 2015 to June 2016. These findings emerged from an earlier project at the National University of Singapore's Lee Kuan Yew School of Public Policy, in collaboration with Chiang Mai University and the Government of Thailand's Office of the Narcotics Control Board.

\section{Prologue: Lowland Intrusions in Southeast Asian Highlands}

Put vegetables in the basket: put people in the Muang (village).

- Thai saying

Van Schendel (2002) coined the word "Zomia" to describe the upland southeast Asian land massif which stretches from Vietnam to Tibet, and which includes Northwestern Thailand: an area traditionally resistant to centralized rule due to its high elevation, extensive forest cover, rugged topography, and the friction which results. Unlike monocropping lowland Thais, Bamars and others who often cultivate Padi rice, highlanders, including Thailand's Karen, Akha, Hmong, Lahu, and Lisu, cultivate a wide variety of crops that are hard to seize and tax, such as tubers. Their swiddening keeps them mobile, and their societies do not allow for the emergence of centralized rule: egalitarianism predominates amongst highlanders, and Myanmar's Kachin would go so far as to kill emergent leaders who seemed too ambitious (Leach, 1954).

Scott (2009), Van Schendel (2002) and others postulate that much of the Zomia population, including Karen, migrated to the hills in order to escape from the centralizing rule of lowland and wet-rice cultivating states that sought to capture and transport populations near to wetland rice producing areas, putting them to work cultivating monocrops which could then be taken, taxed, and stored for long periods. In additional to monocropping, these lowland states were characterized by permanent settlements; uniformity of culture, language, and education; the propagation of dynastic myths to justify rule in cosmological terms; the record-keeping made possible by literacy; the levying of tax; and conscription in pursuit of all of the above. Such states thrived, to the benefit or emerging elites and dynasties, and to the chagrin of captured populations that eventually became the members of uniform ethnicities and religious groups. The Padi state which caused the most flight was Han China, which caused wave after wave of non-Han to flee, first from the river valleys of central China, and then from Sichuan and Yunnan, as changing dynasties seized more land and people. Those who did not flee eventually became Han. Tai people 
originally fled Han expansion, but they replicated Han practices in the lowlands they settled in, and eventually the most successful of the Tai statelets, Thailand, posed the same threat to other highlanders that Han once posed to them as they, and their lowland Bamar neighbors, encroached upon the hills. Highlanders fleeing an expanded state did not only constitute the constructed ethnicities of highland populations; they were also constituted by select Bamar, Han, Tai and other lowlanders who sought freedom in the forests and hills.

The lowland Thai state grew from struggles with Khmer and Bamar neighbors that warred against one another in order to capture populations rather than territories. Thailand's position between French and British colonies served as a buffer between the two and so the state consolidated internally, expanding rule into peripheral and highland areas not claimed by European powers.

King Chulalongkorn, arguably the father of the contemporary Thai state, viewed highland tribes paternally, seeing them as nak anurak or benign savages (Renard, 2001); he also regarded them as Thai subjects. Contemporary authorities may regard Karen and other hill tribes as a less civilized form of Thai, but they regard them as relatives nonetheless. This attitude of benevolent superiority has percolated into much of the civil service ${ }^{1}$.

\section{A Brief History of Opium in Southeast Asia}

The opium poppy (papaver somniferum) is indigenous to the eastern Mediterranean, and was first described by Hippocrates. From Anatolia its cultivation spread to the Balkans, Iran, India and China, where it was first used as medicine a millennia ago.

Refugees entering highland southeast Asia in flight from Han Chinese expansion and successive failed rebellions likely brought opium poppy with them from Sichuan and Yunnan, where it was long cultivated and consumed, by Hmong and Lisu in particular ${ }^{2}$, but. Opium usage became incorporated into the hill tribe cultures of Southwest China, Northern Thailand, Northern Laos, and Northwest Myanmar, as a social and a religious activity. Opium was used as currency; many products were until recently priced in joi of opium. Opium was also a means to store wealth: unlike other crops, it travels well, and can be stored for long periods without degrading. It became a representation of stability, continuity, and wealth, its seed given by parents as wedding gifts to children leaving the household. Opium was also broad-spectrum medicine for a variety of physical and mental ailments, its persistence enhanced by the remoteness of many highland communities to other treatment options. It reduces hunger pangs. Lastly-or perhaps firstly-people like to get high.

British India seized upon opium as their opportunity to "right" the balance of trade issue with China, and India's chronic shortage of silver, by exporting opium to China and other markets. Later waves of Chinese labor migration to Southeast Asia's British and French colonies as well as Siam in the $19^{\text {th }}$ and $20^{\text {th }}$ centuries brought their addiction with them. The Thai King Rama II first banned opium in 1811, but Siam ultimately bowed to British pressure; Rama IV legalized opium again (it would not become illegal again until 1958) instituted a government opium monopoly. The state benefitted: at the end of the $19^{\text {th }}$ century, monopolies on opium, alcohol and gambling constituted at least $40 \%$ of Thai government revenue (Lintner, 2000). Whilst opium was wholly imported from British India, the possibility of cultivating opium outside state monopolies and selling at monopoly prices was soon acted upon by traders, corrupt officials, and holders of monopoly concessions. Highlanders were encouraged to plant more opium, which they would exchange for rice. This also occurred in China, with illicit opium cultivated in Yunnan finding its way into the Thai drug market. The British increased opium cultivation in Shan state, which borders NW Thailand, after they absorbed Myanmar into India in three stages of conquest.

Opium cultivation in Thailand did not begin in earnest until the 1940s. The fall of China's Guomindang (Kuomintang, hereafter KMT) to the communists in 1949 led to the remnants of the

\footnotetext{
${ }^{1}$ Interviews, ONCB, Chian Mai \& Omkoi, December 2015/ March 2016. Many government interviewees regard their work as a civilizing mission.

2 Interviews, villagers, CRSPO, ONCB, Mae Tuen/ Omkoi town, Omkoi, March 2016.
} 
KMT fleeing to Myanmar, where they expanded cultivation of the only cash crop in northern Shanopium, which would reach international markets via Bangkok. Systematic cultivation percolated into Thailand with highlanders fleeing KMT conscription and taxation (McCoy, 1973, Lintner, 1999); Thailand's hill tribes in remote areas became the primary cultivators of the crop, although the profit accrued elsewhere, with KMT and Chiu Chau ${ }^{3}$ Chinese networks. Demand for Southeast Asian opium exponentially increased as a result of the success of eradication programs in the Balkans, Anatolia, and Iran; organized criminal syndicates searched for new sources of opium, and found it in the Golden Triangle (McCoy, 1973). In Thailand, this illegal economy operated with the implicit involvement of the Thai police and army that fought one another over control of the trade; despite the illegality of the substance, law enforcement did not begin until 1984 (see below). Hill Tribe swiddening (or pejoratively, "slash-and-burn") agriculture (Thai: Rai Mun Wian; Burmese: Taungya), historically a sustainable farming practice practiced by highlanders, mutated into the clearance of entire hillsides for poppy in Shan and northwest Thailand. Thai communist insurgents also profited from this trade; highlanders were their farmers and foot soldiers. Opium became central to the dominant lowland Thai discourse on hill tribes. It was in this era especially that, for many lowland Thai, highlanders-swiddeners, opium growers, traffickers, rebels-became associated with environmental destruction, crime, and threat. These stereotypes, which do not stand up to even casual scrutiny. have created an atmosphere of suspicion and distrust which continues to color the lowland - hill tribe relationship.

\section{The "War on Drugs" and the advent of Alternative Development}

Northern Thailand's opium economy began to wane in the early 1970's, when United States President Richard Nixon declared a "War on Drugs" in response to a rising urban heroin epidemic which was partly fueled by addicted American soldiers returning from Vietnam. The Thai government, with US pressure and funding, began treating opium as an illegal substance and poppy as an illegal crop. Elements of the Thai state once involved in cultivation and trafficking began their own disentanglement at this time. The government increased the scale of alternative livelihoods programs which had initially begun under the auspices of Thai King Bhumibol Adulyadej's Royal Project (est. 1969). The Royal Project's approach to alternative livelihoods included:

1. Research and development of geographically suitable alternative crops which would not compete with lowland products;

2. Agricultural extension services including provision of seeds, fertilizer, training, and construction of supporting infrastructure (dams, irrigation, farm feeder roads, etc.);

3. Post-harvest and value-added processes, such as transportation, grading and packing, food processing, market development, etc.

While the United Nations Development Program, working alongside the Royal Project, initially managed many alternative development programs on behalf of the state (Renard, 2001), the Thai Government soon created a specialized agency, the Office of the Narcotics Control Board (hereafter ONCB), to oversee Thailand's drug control policy, alternative livelihoods and (later) eradication in particular. In line with the implicit mission of alternative development as an exercise in the consolidation of state power and the weakening of threats to the state, the ONCB established its first five regional offices in Communist Party of Thailand (CPT) insurgent strongholds (Race, 1974), where they worked as extension agents: earlier state prohibitions on swiddening and logging made many Highlanders eager CPT recruits.

The Royal Project introduced over 150 new crops to opium poppy farmers, including Arabica coffee and tea. Other less-valuable crops included apples, beans, cabbage, corn, decorative flowers, herbs (seasoning), lettuce, peaches, and so on. Padi rice was also encouraged. Issues arose: cabbage cultivation was surprisingly a better earner than opium but only when farmers over-used chemical fertilizers and pesticides (Renard, 2001), and only in the first year of cultivation; prices

\footnotetext{
3 alt: Chao Chu / Teochew / Chaozhou

${ }_{4}^{4}$ Interviews, ONCB, Chiang Mai, December 2015.
} 
soon crashed, and chemicals were soon banned due to the contamination of water sources in watershed areas. The same happened with tomatoes; these initial failures caused many former opium cultivators to abandon the project ${ }^{5}$.

The government established price floors for alternative crops and became the guaranteed buyer for Royal Project produce, in order to match the price farmers once earned from opium poppy cultivation. The Royal Project initially focused on monocropping, which served to make highland participants more reliant on the cash which their monocrop could earn, which they could then use for further nutritional diversification. This was an aspect of lowland "best practices" transplanted to an area which was not appropriate for it, and the Royal Project de-emphasized monocropping after the first decade ${ }^{6}$.

Poppy eradication did not begin until 1984, simultaneous to disarming and demobilizing (and, in the Pieng Luang area, killing) the last vestiges of KMT forces on Thai territory, as well as expelling Khun Sa. This was a full 15 years after alternative development began, when suitable alternative crops were in place; the ONCB coordinated eradication efforts which were primarily conducted by the $3^{\text {rd }}$ Army. In addition to the destruction of crops, authorities began actively arresting cultivators. Between 1984 and 1985, Thailand's area under cultivation dropped from 8,290 to 2,428 Ha (Renard, 2001), and accordingly rose in Myanmar7, where the opium harvest, from an average of $300-400,000 \mathrm{KG}$ per year, would peak at 1,500,000 KG in the mid-1990s; this peak coincided with government ceasefires with numerous highland insurgents emerging from the collapsed Communist Party of Burma. The new groups, especially Wa and Kokang, were then able to concentrate on drug production. Cultivation also shifted to Laos, peaking at $126,654 \mathrm{KG}$ in the 1990s.

Cultivation persisted, however, in remote areas which the state had difficulty accessing or maintaining a presence in. The evasion strategies cultivators developed resulted in staggered crops which sprouted on those same plots destroyed by the army, weeks after they departed. A poppy growth cycle is roughly 3 months, but the annual opium-planting season is 8 months; several overlapping planting cycles occurred. New poppy fields were established further from settlements; no information connected cultivator to crop unless they were apprehended on site. Plots grew smaller, ultimately averaging $0.25 \mathrm{Ha}$. Planting occurred on steep slopes, difficult to detect from spotter planes (and later, satellite imagery). Even today there remain areas that the state cannot see. The friction of terrain remains as important now as it was in colonial times.

Harm Reduction was also a late addition to Thailand's drug control policy. Thailand's initial response to its multifaceted drug problem was driven by foreign, primarily American, concerns. As the problem was considered international and not local, the Thai government's approach concentrated only on the elimination of supply. Only in the 1990s did Thai drug control policy begin to address issues of local addiction, firstly of heroin (which for a brief period in the 1980s and 1990s exploded in young highland populations, Hmong in particular, before AIDS just as rapidly killed the highland injecting population), and secondly of opium: authorities belatedly noted that grassroots farmers of opium poppy were also consumers of a culturally acceptable product, and therefore demand required addressing as well as supply (Anderson et al., 2016). Over the course of alternative livelihoods and eradication, rehabilitation and harm reduction services grew in demand

\footnotetext{
5 Interviews with project participants, Nong Tao, June 24, 2016, and with ONCB, June 21, 2016.

6 Interview, Phaw Luang Jorni Odochao, Nong Tao, Chiang Mai, June 24, 2016.

7 By the late 1980s Myanmar was the world's largest supplier of heroin, which was also used as a currency because of a collapse in the value of the Kyat. Afghanistan would soon surpass Myanmar: US government pressure on Myanmar's State Law and Order Restoration Council to crack down on heroin-manufacturing insurgents, most notably Khun Sa's Mong Tai Army. The world epicenter of poppy cultivation and heroin manufacture soon shifted to Afghanistan, where the Mujahideen group Hizb e Islami began synthesizing heroin in Helmand after the Soviet withdrawal in 1989. The Taliban's declaration of heroin manufacture as haram or forbidden in the late 1990s caused cultivation to shift back to Myanmar.
} 
due to the reduction in heroin and opium supply throughout the 1990s: qualitatively this is visible, but figures are unavailables.

\section{Historical Experiences with Alternative Livelihoods: Doi Laan, Chiangrai}

"Doesn't the state have a responsibility to protect us, to not let us be taken advantage of?"

- Mimi Saeju Win ${ }^{9}$

The experience of Doi Laan is emblematic of the wider disruption in cultures and economies caused by alternative development and eradication. Doi Lann is a Lisu village in Chiangrai province. The majority of Lisu there were involved in opium cultivation and sale. Alternative development projects began in the early 1970's but opium remained the mainstay of the village economy until 1985 , when the military arrived. Mimi Saeju Win was a child at the time; she recounted the arrival of helicopters, followed by uniformed men in trucks. Doi Laan's people fled into the forest while their crops were torched. The Royal Project and a German bilateral development project introduced tomatoes and cabbages but the Lisu quickly fell under the sway of lowlanders who paid below-market prices and then cashed in on the guaranteed price floor paid by the Royal Project. Farmers switched entirely to Arabica, and grow it because it takes less effort, even though the price is still fixed by middlemen at 20 to 25 baht per kilo.

Eradication, for the Lisu, was a significant cultural and economic disruption; opium was the surest sign of wealth in Lisu society. Mimi notes that Lisu women lost much of their household authority at the onset of eradication: women served as opium business managers and traders, and the loss in income from alternative crops affected their status. Doi Laan's men became unhinged as household incomes plummeted. Alcoholism increased, as did use of heroin, amphetamine-like stimulants (ALS), and prostitution; injection and prostitution heralded an HIV epidemic that swept Doi Laan beginning in the early 1990s. Many Lisu previously involved in opium began smuggling ALS from Wa and Kokang areas of Shan state, Myanmar, into Thailand, and a number of these Lisu smugglers and dealers were executed during Thaksin Shinawatra's "war on drugs" in 2003.

Interviewees note that, if many Lisu and other hill tribes had a choice, they would cultivate opium poppy again.

\section{Contemporary Impact of past policy}

The success of the overall alternative livelihoods and crop substitution program in Thailand did not result from substitute crops increasing incomes; the threat posed by eradication and increased law enforcement/ state surveillance, and the potential loss of both income and freedom, were primary factors in the decisions of former cultivators to switch crops ${ }^{10}$. In order to conquer a place, one must first map its people (Anderson, 2006; Scott, 1998; Scott, 2009; Winichakul, 1994). This is doubly true when a stateless area's resources are utilized by a stateless people in a manner different from what the state intends; contestations over resources are implicit challenges to legitimacy. The state's bureaucracy and coercive authority led to changes more than any new crops-none of which provided the same level of income that opium poppy cultivation did. But the price floor established by the Royal Project partially bridged the gap between illicit and licit income. The Royal Project continues to pay inflated prices for substitute crops.

\footnotetext{
8 Interview, public health official, Omkoi, March 2016.

9 Interview, Mimi Saeju Win, Chiang Mai, June 22, 2016.

10 Interviews with former cultivators, Mae Tuen, Feb 2016; with ONCB officials, Chiang Mai, Dec 2015- June 2016; with Mimi Saeju Win, Chiang Mai, June 22, 2016; with Phaw Luang Jorni Odochao, Nong Tao, Chiang Mai, June 24, 2016.
} 
Citizenship: An important factor in the success of alternative livelihoods, according to Renard (2001) and others, was the awarding of Thai citizenship to hill tribe members: citizenship offered the possibility of land tenure. Encouraging crop substitution is implicitly an encouragement in long-term investment, particularly for estate crops such as coffee, tea, and orchard fruits. Arabica coffee is a good example; it grows at the same altitude as opium, travels well, offers better returns compared to short-term crops, and it requires the shade of larger trees, so deforestation is not an issue: it is an ideal alternate crop. But Arabica takes at least 3 years to reach maturity for harvesting. Providing this tenure to farmers encouraged them to shift away from an illegal crop with a short cultivation window and a high rate of return by giving them the security of knowing they would not be expelled from the land they cultivated. In areas designated as protected by the Royal Forestry Department (see below), limited tenure was also allowed, sometimes grudgingly (Renard, 2001). Citizenship gives those who hold it a vested interest in the state and its laws; it provides minimum levels of security and protection, even in areas where the rule of law is still in adaptive phases. In Thailand's evolving state-citizen compact, it provides free education and subsidized health care. It allows ownership of land and access to credit, and is necessary for longer-term investments. The further one enters remaining contemporary opium cultivation areas (such as Omkoi- see below), the larger the percentage of the population lacks it.

Roads and electricity: The impact of crop substitution cannot be disentangled from other forms of development, namely road building, followed by electrification. Roads served a dual purpose: to transport administrators and security actors in, and transport substitute crops out with as little damage to the product as possible before it arrived at market.

Crop substitution and the end of Swiddening: The alternative livelihoods model, focused on static agriculture and livestock, was antithetical to highland swiddening traditions: while alternative development was primarily concerned with opium poppy, it implicitly targeted swiddening as well. Alternative development projects largely ended the symbiotic relationship between hill tribe swiddeners and forests. And in the areas it was successful, it changed the very reason why highlanders cultivated crops: from household unit consumption to sale in markets.

The Royal Forestry Department was initially created to protect and regulate Thailand's teak supply in the late 1800s, after highland Karen began "illegally" selling teak to the British in Shan and the French in Laos. At that time all forests were declared the property of the state. Ironically, RFD can be historically implicated in the introduction of opium to Karen in Nong Tao and other areas of Chiang Mai: they banned Karen from growing rice, which would have required large-scale forest clearing, but allowed them to grow opium, which required much less clearing. The Karen would trade the opium for the rice they were prohibited from growing directly; the government taxed the trade as well. RFD's mandate expanded into watershed conservation as Thailand's forest cover declined from 53.33\% to 30.92\% of overall land area between 1960 and 2006 (Ongprasert, 2011). RFD's policing of forest subcontracted Thai demand for forest products into Myanmar (Smith, 1994), Karen National Union areas in particular ${ }^{11}$. Since its inception, the RFD has been at loggerheads with hill tribes, denouncing and seeking to end swiddening, which it and other agencies uniformly oppose under the mistaken impression that it is environmentally harmful and leads to large-scale deforestation, while all available studies demonstrate that it is a rejuvenating practice $^{12}$ (Asia Indigenous People's Alliance, 2012; Bruun et al., 2009; Erni, 2009; Laungaramsri, 2005). Karen leader Phaw Luang Jorni Odochao notes a particular irony: "The Thai government blames us for deforestation. But where Karen live, there are forests; where Thais live, there are none." Further, the wholesale land clearances by KMT, Hmong, Lisu and others in the heyday of opium cultivation was not swiddening, but for many lowlanders, the practices were one and the same. While opium cultivation declined, so did swiddening.

\footnotetext{
11 Interview, KNU representative U Mam Char, Taung Galay, Kayin State, Myanmar, December 2016. The KNU has recently declared a moratorium on forestry in its areas, and signed an MoU with the World Wildlife Foundation (Irrawaddy, 2016).

12 This would change if the populations practicing it increased, but anecdotally, the opposite occurred, with younger generations seeking livelihoods other than shifting agricultural practice.
} 
However, the RFD was forced to adapt to the wishes of the Royal Project. Were they given a free hand they may have simply expelled highlanders from the areas they were tasked to protect, at the Conservation Law which defined RFD duties had declared vast swathes of highland territory "protected forest", in which human habitation was illegal, even though numerous settlements and peoples pre-dated the law. According to the late King Bhumibol Adulyadej "in national forests that the authorities declare to be reserved or restricted, people have long been there. It is strange to enforce the law against people who live in such areas, which have always been non-reserved, but only lately declared reserved because of some lines drawn on paper. The problem occurs when those boundaries are drawn, causing the people inhabiting those areas to become "lawbreakers". In terms of legislation, they may be seen to violate the law, because the law is legally passed. However, if we consider the issue naturally as to who is actually breaking the law, it becomes clear that the lawmakers are, because the people lived in the area long before the law was enacted ${ }^{13}$." The king forced a compromise: swiddening would end, but populations would remain.

The conflict between RFD and the hill tribes continues in 2017, with RFD/ DNP continuing to remove Karen, Hmong, Lisu and others from lands they have dwelt in for centuries. The current Thai junta, the National Council for Peace and Order (NCPO), issued order 64/2014 to protect and restore existing forests; shortly after, the NCPO issued order 66/2014, to shield the poor from t64/2014. However, DNP seems to have embraced the former and ignore the latter.

With the passing of King Bhumibol, a significant restraint on the RFD and DNP may have been lifted.

Nutrition: The nutritional diversification accompanying former swiddening techniques ended due to monocropping substitution, and rural food security declined as a consequence. This is the opposite of claims made by alternative development practitioners ${ }^{14}$ who assert that the cash earned from monocropping allows for the purchase of varied foodstuffs which were once cultivated. The market price of a monocrop, however, is volatile, especially for high-value crops such as coffee, and so a collapse in its price signifies a collapse in household purchasing power, and therefore, a collapse in the collapse of a food supply which was previously a constant. This reduction in food security is not quantitatively measureable due to a lack of preserved data from past projects and a lack of previous monitoring and evaluation, but Karen and other hill tribe interviewees who experienced this attested to it.

Increasing dependence on markets and out-migration: The reduction in swiddening further integrated highland cultivators into Thailand's "cash" (non-opium) economy, thus increasing their dependence on the state and its markets, and necessitating non-traditional forms of work paid in currency. This integration also encouraged seasonal and sometimes permanent migration of highlanders to towns and cities, often for construction and other casual labor: in many highland areas, remittances became the primary income streams for cash-based needs. Select Chiangrai activists make a connection between declining opium cultivation and increasing trafficking in tribal women to brothels in the south, but this is anecdotal.

Gender imbalances: The end of opium cultivation also instigated a disruption in gender relations amongst tribes such as Lisu. Hutheesing (1989) reported that, among the Lisu she lived with in the early- to mid-1980s, women's traditional roles as money managers for opium incomes were disrupted, with significant negative impacts on their status in the village. Opium was central to Lisu life, Hutheesing (ibid.) and others note ${ }^{15}$, and the enforced absence of it resulted in high rates of infidelity, alcoholism, amphetamine and heroin abuse, with resultant increasing HIV transmission in Lisu villages.

Other Impacts: Hill tribes saw alternative development as an imposition from Bangkok that stripped them of their culture and sought to turn them into caricatures of lowland Thais (Jantakad and Carson, 1998; Renard, 2001): they were the passive recipients of such programs, and their

\footnotetext{
13 From a speech given by King Bhumibol Adulyadej, June 27, 1973. Translation by Patamawadee Jongruck.

14 Interview, HRDI, Chiang Mai, March 2016.

15 Interview, Lisu activist, Chiang Mai, June 22, 2016.
} 
voices played no role in the shaping of them; nor did they choose which new crops they might cultivate.

All of these impacts led Margaret Mead and other anthropologists to condemn alternative livelihood programming, erroneously alleging a cultural genocide (Washburn, 1998).

Overall, state surveillance and control implicitly increased in areas where it was previously not present, through roads, troops, and bureaucrats, and non-state areas were integrated into the Thai state over time by virtue of this coercion, as well as Thai in-migration to the highlands and the spreading usage of the Thai language and the increased embeddedness of its culture. This era was also marked by the elimination of non-state rivals such as former KMT and communist insurgents.

Opium, in this era, can be seen as less of a commodity and more of a proxy indicator for the state of hegemonic power relations (Siriphon, 2001) between lowland and highland, shifting inexorably in favor of the lowlands by the lever of alternative development.

This state imposition of rule on egalitarian highland areas, touched off decades before by flight of the KMT, is referred to as "development". But in its economic conversion of the highlands to make it serve lowland interests, it may be better described as "capitalist terraforming".

\section{Remaining Opium Poppy Cultivation in Northwest Thailand}

While opium poppy cultivation declined significantly, it did not end. The majority of known opium cultivation in contemporary Thailand occurs in Chiang Mai's Omkoi district: an area bypassed by a half century of alternative development and eradication, although residents note that opium was cultivated there since at least the 1960s. ONCB recorded significant cultivation increases in the 1990s, but inexplicably stopped monitoring the district around 1998, only beginning again in 2009; since then, cultivation rates have ebbed and flowed in a manner unconnected to eradication impacts (Jongruck, 2012; ONCB, 1995-2015). 90\% of Omkoi is classified as a national forest C-Zone reserve area in order to protect a watershed so important that the Thai authorities consider it a national security issue: people are prohibited from inhabiting, cultivating or otherwise utilizing it. But a large ethnic Karen population of swiddening cultivators has lived there since long before the law that outlawed them was created. They reside in areas unconnected to the state by road, with limited or no access to schools, health centers, and other services: they are the grassroots cultivators of Omkoi's opium supply, sold onward to opaque networks the state is struggling to identify. While past studies (Hinton, 1983) allege that Karen don't cultivate opium, field research demonstrates that, not only are Karen growing opium now, but they have been growing in Omkoi and other areas of Chiang Mai for at least 50 years. While most Karen no longer engage in cultivation or consumption, in remoter parts of Omkoi their cultivation rates are the highest in Thailand. Thai and US drug control efforts historically overlooked this district, and possibly others hosting drug production not yet identified by the state, because it did not host an interrelated communist insurgency, nor were cultivation rates as high as other areas of NW Thailand. The government has recognized the scale of cultivation and since 2009 has taken a novel "network governance" approach to suppression (Jongruck, 2012), utilizing lessons from former cultivation areas (Anderson et al, 2-15)

Opium's profit hardly accrues to the farmer. Omkoi's Karen grow opium because they have little other choice. The encroachment of "development" upon Omkoi's Karen has already occurred through their growing reliance on lowland markets where currency is the only form of exchange, and opium is the highest- value cash crop around. Their lack of citizenship precludes them from land tenure which might incentive them to grow estate crops with a lower rate of return and a longer cultivation period, and their statelessness also precludes them from services, credit and other protections. Even if they had citizenship, their presence in a C-Zone reserve area still leaves them "illegal". And if these issues are all overcome, a stark truth remains: there is no alternative crop that can equal the price a farmer earns from opium. Previous programs did not succeed because of agriculture, but because of the increased presence of the state.

That presence, however, is growing, most palpably in eradication, law enforcement, and market encroachment. Omkoi is 1960s highland Thailand in microcosm; it hosts the historical 
extension of lowland Padi state power into an ungoverned, untallied, ephemeral highland-one of the last areas in Thailand to undergo this transformation.

\section{Conclusion}

Thomas Hobbes's Leviathan serves as the foundational text of contemporary Realist state philosophies: people voluntarily surrender themselves to the munificent state in order to benefit from its protections and escape from the state of nature- the unceasing war of 'all against all'. But the reality is that states, organized by violent entrepreneurs, came to dominate not because they brought peace to a State of Nature, but because they were logistically more effective and coercively more brutal than competing entities when it came to waging war, holding territory, mobilizing labor/ conscription, and levying 'tax' (Tilly, 1985): they held 'a decisive advantage in the power to kill" (Landes, 1998: 88). Over time, firstly in Europe, and later, in the colonies, these exploitative entities developed beyond their solely violent and coercive beginnings; they became 'legitimate' by providing protection not just from themselves, but also from others, and they began to provide services ${ }^{16}$ : transportation and communications infrastructure, health and education, limited welfare and social protection mechanisms, a (usually) impartial police and judiciary protecting citizens from one another and from the state, and so on ${ }^{17}$.

Northwestern Thailand's highland inhabitants once avoided expanding lowland empires, Thai as well as Bamar, by taking advantage of the friction of topography that the highlands offered. In a world devoid of cash, where land was rich and the people few, the state was an imposition. But the lowland coercive authority that these highland inhabitants avoided has changed.

The Hill Tribes have also changed: their lives would not continue in a vast outdoor museum. Ethnic identities have always been in flux; globalization increases this process. Highlanders are drawn to the state, and absorbed into its cash economy: they need the tools that will help them better navigate it. These tools did not prevent highlanders from becoming more Thai and less Akha, Karen, Hmong or Lisu; as traditional lifestyles change, painful decisions must be made, but education, citizenship, and market skills were all tools which highlanders could use to play more of a part in those decisions, rather than simply have decisions made on their behalf, by their own leaders or by the state. Development, in this case, was self-defense.

The Thai state eliminated its position as a source of opium for international illicit drug markets decades ago. That success occurred with a great cultural cost to the hill tribes: the symbiotic relationship between people and land ended. This was, and remains, traumatic. Eradication worked due not only to eradication, arrests, and crop substitution; it worked because the imposition of law occurred consecutive with benefits to hill tribes such as the provision of citizenship and the rights and responsibilities it embodies; the end of inaccessibility through the establishment of roads; increased access to schools and health care; access to markets and to credit, and all manner of other services and obligations that, together, constitute an ever-evolving social contract.

Conflicts of Interest: The author declares no conflict of interest.

\footnotetext{
16 State theorists and propagandists built on Hobbes and developed mythologies to justify state primacy by expanding the notion of a pre-state war of perpetuity that the state served as an antidote for; the 'necessity' of states was expanded across the globe, with all 'primitive' people imagined to voluntarily surrender to nearby states in order to gain the peace and protection these entities offered. Whilst these claims may have some significant historical precedents (especially Hobbes, whose writings were entirely shaped by the 30 Year's War, when the war of 'all against all' killed one-third of the population of the German-speaking lands of Central Europe: the Treaty of Westphalia, which ended that war, was the beginning of the primacy of the state system), they are generally inaccurate outside of European contexts.

17 Contemporary Thailand varies from a key attribute of the contemporary northern European state, namely a military that solely serves as the implementer of civilian-driven policy related to external defense.
} 
Acknowledgments: The author extends his greatest thanks to Dr. Patamawadee Jongruck at the Chiang Mai University School of Political Science and Public Administration, as well as Tian Yeow Tan and Francis Woodcock; all participated in a previous research project at the National University of Singapore and conducted field research with the author in Omkoi and further afield. Micah Fisher at the University of Hawaii also provided valuable commentary. The author wishes to thank the Office of the Narcotics Control Board (ONCB) Region 5, especially Jerrapan Mugura, former ONCB Director of Strategy and Administration, and Karn Thaiyapirom. ONCB Region 5 representatives Director Watin Damronglaohapan, Director Pipop Chamnivikaipong, Thippamet Sangawanna, Kraivudh Maneeratana, and Varisara Yasamuth; 3rd Army representatives including Colonel Suraput Numlong, 7th Infantry Division; Professor Ora-orn Poocharoen, Dean of the Department of Political Science and Public Administration at Chiang Mai University, and Professor Panom; Raks Thai Foundation Program Coordinator Sarinthip Promrit; Pattana, Royal Project extension director; Khun Tuen Noi village inhabitants including village leader Pamoti; Bi Po village Tambon Administrative Officer Som Chai; Musa Bat Tam Village inhabitants including the treatment camp interviewees; Mimi Saeju Win of the Chiang Mai Lisu Cultural Heritage Center; Nong Tao Village Leader Phaw Luang Jorni Odochao; Jowalu Oshi Chindanai, and Yonatan Keller. The author also thanks Faculty and Staff at the National University of Singapore's Lee Kuan Yew School of Public Policy. Any errors of fact or interpretation are the fault of the author.

\section{References}

Anderson, B.O.G. (2006). Imagined Communities: Reflections on the Origin and Spread of Nationalism. London: Verso.

Anderson, B., Tan, T.Y., Woodcock, S., and Jongruck, P. (2016). Thailand's Last Opium War: Governance and Illegality in a Highland Periphery. National University of Singapore Governance Study Project.

Asia Indigenous People's Alliance. (2012). Drivers of Deforestation? Facts to be considered regarding the impact of shifting cultivation in Asia. AIPP. Retrieved from http://ccmin.aippnet.org/attachments/article/956/Driver_\%20of_Deforestation.pdf in June 292016.

Bruun, T. B., De Neergaard, A., Lawrence, D., \& Ziegler, A. D. (2009). "Environmental Consequences of the Demise in Swidden Cultivation in Southeast Asia: Carbon Storage and Soil Quality." Human Ecology 37(3), 375-388; ASB-Indonesia Report Number 4, Bogor.

Erni, C.. (2009). Shifting the Blame? Southeast Asia's Indigenous Peoples and Shifting Cultivation in the Age of Climate Change. Paper presented at Adivasi/ST Communities in India: Development and Change, Delhi, August 27-29.

Hinton, P. (1983). Why the Karen do not Grow Opium: Competition and Contradiction in the Highlands of North Thailand. Ethnology 22(1): 1-16.

Hutheesing, O. K. (1989). Emerging Sexual Inequality among the Lisu in Northern Thailand: The Waning of Dog and Elephant Repute. Leiden: Brill.

Irrawaddy. (2016). KNU Signs Forestry Memorandum with WWF. November 9. Retrieved from http://www.irrawaddy.com/news/burma/knu-signs-forestry-memorandum-with-wwf.html. in January 4, 2017.

Jantakad, P., \& Carson, S. (1998) Community Based Natural Resource Management from Villages to an Inter-Village Network: A Case Study in Pang Ma Pha District, Mae Hong Son Province, Northern Thailand. International Workshop on Community-Based Natural Resource Management, World Bank, Washington, USA.

Jongruck, P. (2012). Network Governance through Resource Dependence Theory: a Case Study of Illicit Drug Policy in Thailand. PhD dissertation, University of Manchester (UK).

Landes, D. S. (1998). The Wealth and Poverty of Nations. New York: Norton.

Laungaramsri, P. (2005). Swidden agriculture in Thailand. Myths, realities and challenges. Indigenous A airs 2/05. Copenhagen: IWGIA. 
Leach, E. (1954). Political Systems of Highland Burma: a Study of Kachin Social Structure. London: Anthlone Press.

Lintner, B. (1999). Burma in Revolt: Opium and Insurgency since 1948. Chiang Mai: Silkworm Books.

Lintner, B. (2000). An Overview of the Golden Triangle Opium Trade. Chiang Mai: Asia-Pacific Media Services.

McCoy, A.W. (1973). The Politics of Heroin in Southeast Asia. New York: Harper and Row.

ONCB. (1995-2015). Opium Cultivation and Eradication Reports for Thailand.

Ongprasert, P. (2011). "Forest Management in Thailand." Participants Reports on Forest Resources Management: 151.

Race, J. (1974). The War in Northern Thailand. Modern Asian Studies 8/1, pp. 85-112.

Renard, R.D. (2001). Opium Reduction in Thailand, 1970-2000. Chiang Mai: Silkworm Books.

Scott, J.C. (1998). Seeing Like a State: How Certain Schemes to Improve the Human Condition Have Failed. New Haven: Yale University Press.

Scott, J.C. (2009). The Art of Not Being Governed: an Anarchist History of Upland Southeast Asia. New York: Yale University Press.

Siriphon, A. (2001). Opium and the Hmong: Dynamism, Diversity and Complexity of Identifies of a Marginal people. Master's Dissertation, Chiang Mai University, Unpublished.

Smith, M. (1994). Burma: Insurgency and the Politics of Ethnicity. London: Zed Books.

Tilly, C. (1985). "War Making and State Making as Organized Crime", in Evans, Peter, Dietrich Rueschemeyer, and Theda Skocpol. Eds. Bringing the State Back In. Cambridge: Cambridge University Press.

Van Schendel, W. (2002). Geographies of Knowing, Geographies of Ignorance: Jumping Scale in Southeast Asia. Environment and Planning D: Society and Space 20: 647-668.

Washburn, W. E. (1998). Against the Anthropological Grain. New Jersey: Transaction Publishers.

Winichakul, S. (1994). Siam Mapped: a History of the Geo-Body of a Nation. Honolulu: University of Hawaii Press. 